\title{
Bleaching of Mustard Oil with Some Alternative Bleaching Agents and Acid Activated Clay
}

\author{
Bijay Krishna De*, Jignesh Dahyabhai Patel, Jignesh Bharatbhai Patel, \\ Vijay Kantilal Patel and Vinay Rajeshbhai Patel
}

Department of Industrial Chemistry, Division of Oils, Fats \& Waxes, Institute of Science \& Technology for Advanced Studies \& Research (ISTAR) (Vallabh Vidyanagar-388 120, Anand, Gujarat, INDIA)

\begin{abstract}
An attempt was made to study the bleaching ability of some alternative adsorbents like rice husk ash $(\mathrm{HC})$, acid activated rice husk ash $(\mathrm{AC})$, rice husk silica $(\mathrm{S})$, and $\mathrm{Al}(\mathrm{OH})_{3}$ gel to replace commercial Acid Activated Clay (AAC, like Tonsil Earth: TE) for bleaching of mustard oil. Quantities of AAC used were varied from 0.5 to $2.0 \%(w / w)$. It was used as such and along with commercial activated carbon $\left(0.25-0.75 \%\right.$, w/w), and laboratory prepared $\mathrm{Al}(\mathrm{OH})_{3}$ gel, rice husk ash and silica isolated from husk. The results show that quantity of AAC to be used can be reduced to 1.00 to $1.25 \%(\mathrm{w} / \mathrm{w})$ by using a combination of $\mathrm{AAC}$ along with rice husk ash; $\mathrm{Al}(\mathrm{OH})_{3}$ gel; rice husk silica either by wet bleaching or by conventional bleaching method.
\end{abstract}

Key words: bleaching, mustard oil, rice husk ash and silica

\section{INTRODUCTION}

Bleaching is an important step in the refining of vegetable oils producing light color oil with simultaneous removal of trace metals, soaps and peroxides ${ }^{1}$. This process has drawn attention to the processors of oils and technologists since it improves the appearance of oil and removes certain materials, which degrades the quality of oil with time.

Among different bleaching methods adsorptive bleaching is most commonly practiced because of its nondestructive nature and can simultaneously remove the said undesired components. Although this method is well established and most frequently used adsorbents are Tonsil Earth (TE) and other acid activated clays [with or without activated carbon] the process has an inherent drawback of higher cost of these earth materials. Research endeavor is therefore being pursued to replace TE either partly or fully.

Pryor et al. have developed a process for the removal of chlorophyll, color bodies and phospholipids from glyceridic oils using acid activated silica adsorbents ${ }^{2}$. They contacted sulphuric acid treated silica with caustic refined soybean oil and got an oil devoid of chlorophyll. Thomopoulos et al. ${ }^{3)}$ studied decolorization of neutralized cottonseed oil and olive oil by activated bleaching earth and mixtures with variable quantities with $\mathrm{MgO}$. They reported addition of $\mathrm{MgO}$ increased the bleaching activity of earth material. In another study Prior et $a l .^{4)}$ used a pretreatment of oil with amorphous silica prior to passing the oil through a packed bed of pigment removal agent. According to them this process offered reduced processing time and an increased filter on-stream lifetime. Proctor and Palaniappan ${ }^{5)}$ used rice hull ash and carbon activated with acid to give a mixture of silicate minerals and carbon to remove carotenoids from soybean oil. They used miscella bleaching process and optimized the bleaching condition. They reported that the performance of activated ash was comparable to the bleaching earth. Liew et al. also studied the bleaching efficiency of rice hull ash obtained by heat treatment followed by washing $^{6}$. Their objective was to adsorb carotene from palm oil. According to them heat treatment of raw rice hulls resulted in the most active adsorbent after acid activation. Silica gel bleaching of rice bran oil in solvent media was carried out by Krishna ${ }^{7}$. A silica gel / oil / solvent ratio of 1:5:5 (wt/ wt/ wt) was reported to be suitable for bleaching. On the other hand Katzer et al. reported a two step procedure for decolorization of oils and fats with adsorbents ${ }^{8}$. In the

\footnotetext{
*Correspondence to: Bijay Krishna De, Department of Industrial Chemistry, Division of Oils, Fats \& Waxes, Institute of Science \& Technology for Advanced Studies \& Research (ISTAR), Vallabh Vidyanagar-388 120, Anand, Gujarat, INDIA E-mail: bijay_de@yahoo.co.in
} Accepted September 30, 2008 (recieved for review May 16, 2008)

Journal of Oleo Science ISSN 1345-8957 print / ISSN 1347-3352 online

http://www.jstage.jst.go.jp/browse/jos/ 


\section{B.K. De, J.D. Patel, J.B. Patel et al.}

study the oils and fats were treated with adsorbents at $65-75^{\circ} \mathrm{C}$ under pressure and then at $85-95^{\circ} \mathrm{C}$ at reduced pressure.

The pertinent literatures show that some work has been done on improving the bleaching efficiency of adsorbent materials and on finding out alternative adsorbents (like acid treated rice husk, silica, $\mathrm{MgO}$ etc.) for bleaching of different oils. Due to higher cost of TE the present investigation aims at reducing the use of TE by using some alternative bleaching agents like rice husk silica, rice husk ash, aluminum hydroxide gel. Mustard oil, which was randomly selected for the present investigation was therefore treated with varying amount of these adsorbents to reduce the color.

\section{EXPERIMENTAL}

\subsection{Materials}

Mustard oil (Brand: Mustola; Manufacturer: NDDB, Anand, Gujarat) was purchased from the local market. Commercial Acid Activated Clay (AAC) like Tonsil Earth (Optimum $210 \mathrm{FF}$ ) was a gift from Süd-Chemie AG; Moosburg; Germany. All other chemicals used were of Analytical Reagent grade and purchased from S.D. Fine-Chem; Boisar; Maharastra). Rice Husk was purchased from local rice mill (Jalaram Seeds and Pulses Ltd., Anand, Gujarat). Activated carbon was purchased from Chiti- Chem. Ltd. (Baroda, India).

\subsection{Methods}

2.2.1 Preparation of rice husk ash (HC) and rice husk sili$\mathrm{ca}(\mathrm{S})$ : Rice husk was cleaned to remove dust and other particles and sun dried. It was then taken in a Borosil glass beaker and burnt the whole mass in direct flame until evolution of fume from the beaker stopped. After that this black material was ground well and used as a rice husk ash (HC).

For making rice husk silica (S) the cleaned rice husk was taken in a crucible and put in a muffle furnace where the temperature was maintained at $650-750^{\circ} \mathrm{C}$ for about seven hours. After that it became white fluffy powder that was stored in bottle.

2.2.2 Acid activation of rice husk silica: For this rice husk silica $(25 \mathrm{~g})$ was taken in a glass beaker, added $50 \mathrm{~mL}$ of sulphuric acid (1N) and stirred well for $30 \mathrm{~min}$. The mixture was allowed to stand for $15 \mathrm{~min}$. and the treated mass of silica was filtered off. The process of acid treatment was repeated once and the acid treated silica was then dried in oven at $100{ }^{\circ} \mathrm{C}$.

2.2.3 Preparation of aluminum hydroxide gel and powder: A definite quantity (Ca. $50 \mathrm{~g}$ ) of aluminum sulphate was taken in a glass beaker (Cap. $500 \mathrm{ml}$ ) and dissolved in 150 $\mathrm{ml}$ of distilled water. To this solution liquid ammonia was added slowly till the $\mathrm{pH}$ of the solution became 8-9 and the precipitation was complete. Then the water was removed by filtration through Whatman filter paper (No. 41). The residue obtained was aluminium hydroxide gel. Some part of it was then taken in a Petri plate and dried in oven at 100 ${ }^{\circ} \mathrm{C}$ till moisture free.

2.2.4 Bleaching of Mustard Oil: Mustard oil sample (Ca. 25 g) was taken in a flat bottom standard joint (B-24) flask. The flask was placed on a water bath kept on magnetic stirrer and the oil was then heated to $90-95^{\circ} \mathrm{C}$ under vacuum (pressure: $30 \mathrm{~mm} \mathrm{Hg}$ ). After that $2 \%$ (on weight of oil) adsorbent was added in the oil and the stirring was continued for about 30 minutes. During stirring the temperature and vacuum was maintained constantly and finally the oil was filtered through Whatmann (No. 41) filter paper. The oil was characterized by determining its color.

2.2.5 Determination of Particle Size: Particle size of the rice husk ash and rice husk silica, used in the present study, was measured in Particle Size Analyzer (Make: Sympatec; Model: Helos-BF; Germany). De-ionized water was used as the dispersant and measuring range was $\mathrm{R}_{5}$ i.e. 0.5 to $875 \mu \mathrm{m}$.

For Wet-Bleaching process after heating the oil to 90-95 ${ }^{\circ} \mathrm{C}$ under vacuum (pressure: $30 \mathrm{~mm} \mathrm{Hg}$ ) a slurry of adsorbents and water having the compositions mentioned in Table 4 was added to the oil. Then stirring was continued for 30 minutes maintaining the temperature and pressure mentioned above; and finally the oil was filtered.

To characterize the oil sample color, content of free fatty acids, peroxide value, iodine value, and saponification value were determined according to the standard IUPAC methods $^{9)}$ for the analysis of fats and oils. Phosphorus content in the crude mustard oil was measured following the standard method of Chen et al. ${ }^{10}$.

\section{RESULTS AND DISCUSSION}

The entire study aims at reducing the use of commercial acid activated clay (AAC or Tonsil Earth) by replacing it partially or fully with some alternative adsorbents. For this crude mustard oil was used as reference. The physicochemical properties of the crude mustard oil used in this present investigation are shown in Table 1. The color (Y+5R: 47 in Lovibond scale using $2.54 \mathrm{~cm}$ cell), content of free fatty acid $(0.8 \%, \mathrm{w} / \mathrm{w})$ and peroxide value ( 15.5 $\mathrm{meq} / \mathrm{kg}$ ) indicate the quality of the oil; whereas, iodine value $(103.9 \mathrm{~g} / 100 \mathrm{~g})$, saponification value $(170.1 \mathrm{mg} / \mathrm{g})$, phosphorus content $(40.6 \mu \mathrm{g} / \mathrm{g})$ and fatty acid profile indicate the authenticity of the oil sample used for the investigation.

The oil was first bleached with different percentages (0.5 to $2.0 \%, w / w)$ of AAC and then with a combination of AAC and activated $\mathrm{C}$ to find out their bleaching effect on the 
mustard oil sample used. Their use is very common and widely practiced, but it was studied to find out the bleaching effect of these samples of $\mathrm{AAC}$ and $\mathrm{C}$ on the used mustard oil sample. AAC was used as standard, with the main objective to reduce its use. As expected it was observed that when the quantity of AAC used was increased more color reduction was achieved. Table 2 shows that a minimum of $1.5 \%, \mathrm{w} / \mathrm{w}$ (on weight of oil) AAC is required to reduce the color of oil to an acceptable level $(\mathrm{Y}+5 \mathrm{R}$ in Lovibond scale to be less than 20 , by using $2.54 \mathrm{~cm}$ cell). When

Table 1 Physicochemical Characteristics of Crude Mustard Oil Used in the Study.

\begin{tabular}{l|r}
\hline \multicolumn{1}{c|}{ Characteristics } & \multicolumn{1}{c}{ Values } \\
\hline Color $($ Lovibond, $2.54 \mathrm{~cm}$ cell) $\mathrm{Y}+5 \mathrm{R}$ & 47.0 \\
\hline Free Fatty Acids $(\%, \mathrm{w} / \mathrm{w})$ & 0.8 \\
\hline Peroxide Value $(\mathrm{meq} / \mathrm{kg})$ & 15.5 \\
\hline Iodine Value $(\mathrm{g} / 100)$ & 103.9 \\
\hline Saponification Value $(\mathrm{mg} / \mathrm{g})$ & 170.1 \\
\hline Phosphorus Content $(\mathrm{mg} / \mathrm{g})$ & 40.6 \\
\hline Fatty Acid Composition $(\%, \mathrm{w} / \mathrm{w}):$ & 1.9 \\
Palmitic acid $\left(\mathrm{C}_{16: 0}\right)$ & 1.7 \\
Stearic acid $\left(\mathrm{C}_{18: 0}\right)$ & 11.2 \\
Oleic acid $\left(\mathrm{C}_{18: 1}\right)$ & 13.8 \\
Linoleic acid $\left(\mathrm{C}_{8: 2}\right)$ & 10.7 \\
Linolenic acid $\left(\mathrm{C}_{18: 3}\right)$ & 1.5 \\
Arachidic acid $\left(\mathrm{C}_{20: 0}\right)$ & 6.6 \\
Eicosenoic acid $\left(\mathrm{C}_{20: 1}\right)$ & 1.0 \\
Behenic acid $\left(\mathrm{C}_{22: 0}\right)$ & 49.8 \\
Erucic acid $\left(\mathrm{C}_{22: 1}\right)$ & 1.8 \\
Lignoceric acid $\left(\mathrm{C}_{24: 0}\right)$ & \\
\hline & \\
\hline
\end{tabular}

the oil was bleached with $2.0 \%, \mathrm{w} / \mathrm{w}$, of AAC the color value of bleached oil became $4.5 \pm 0.10$. Since usually no more than $2.0 \%, \mathrm{w} / \mathrm{w}$, of $\mathrm{AAC}$ is required to be used the use of AAC was restricted to maximum $2.0 \%$, w/w, of oil. Furthermore when some alternative adsorbents were used the quantity of AAC used was restricted to 1.00 to $1.25 \%$, $\mathrm{w} / \mathrm{w}$, due to its higher cost and increase in solid load in bleacher. To characterize the bleached oil samples peroxide value and content of free fatty acids was measured. PV $(3.5 \pm 0.16$ to $0.7 \pm 0.06 \mathrm{meq} / \mathrm{kg})$ reduced drastically but the content of FFA shown no change in its value.

Conventionally, for bleaching purpose, AAC is used in conjunction with activated carbon (C). Bleaching of mustard oil was therefore studied (Table 3 ) by using a combination of AAC and $\mathrm{C}$ too. AAC and $\mathrm{C}$ were used at the following percentages: $1.50: 0.00 ; 1.25: 0.25 ; 1.00: 0.50 \& 0.75: 0.75$ $(\mathrm{w} / \mathrm{w})$. Keeping the total quantity of adsorbent to be used at $1.5 \%, \mathrm{w} / \mathrm{w}, \mathrm{AAC}$ was partially replaced by C. It was found that on slowly replacing $\mathrm{AAC}$ with $\mathrm{C}$ the reduction of color became less. Color value reduced to $11.0 \pm 0.20$, when 1.5 $\%$, w/w, AAC was used; and to $25.0 \pm 0.17 \%$, when $0.75 \%$, $\mathrm{w} / \mathrm{w} \mathrm{AAC}$ and $0.75 \%, \mathrm{w} / \mathrm{w} \mathrm{C}$ was used. Peroxide value also as expected reduced to the range of $1.0 \pm 0.10$ to $2.4 \pm$ $0.17(\mathrm{meq} / \mathrm{kg})$.

Next it was attempted to partially replace AAC with one non-traditional bleaching adsorbent [HC: rice husk ash; containing $55.9 \%$, w/w, C; and then $\mathrm{Al}(\mathrm{OH})_{3}$ gel] following the wet bleaching method (refer to Table 4). The volumetric mean diameter (VMD) of the particles is $43.5 \mu \mathrm{m} ; 10,16$, 50, 84, 90 and $99 \%$ (by-vol) of the particles passes through mesh sizes of 4.75, 7.58, 32.63, 80.07, 97.70 and $178.43 \mu \mathrm{m}$, respectively. Although wet bleaching method is less practiced in industries, due to higher chances of possible degradation of oil, the table shows the use of water with AAC gives better result in terms of color reduction than only AAC (vide Table 2 and 3). Combinations of AAC: water; $\mathrm{HC}$ : water; and AAC: water: $\mathrm{H}$ was used for study. A

Table 2 Bleaching of Mustard Oil Using Commercial Acid Activated Clay.

\begin{tabular}{c|c|c|c}
\hline $\begin{array}{c}\text { Sr. } \\
\text { No. }\end{array}$ & $\begin{array}{c}\text { AAC used } \\
(\%, \mathrm{w} / \mathrm{w})\end{array}$ & $\begin{array}{c}\text { Color of bleached oil } \\
\text { sample }(\mathrm{Y}+5 \mathrm{R})\end{array}$ & $\begin{array}{c}\text { Peroxide Value } \\
(\mathrm{Meq} / \mathrm{kg})\end{array}$ \\
\hline 1 & 0.50 & $37.5 \pm 0.18$ & $3.5 \pm 0.16$ \\
\hline 2 & 0.75 & $30.5 \pm 0.25$ & $3.0 \pm 0.12$ \\
\hline 3 & 1.00 & $28.5 \pm 0.45$ & $2.2 \pm 0.16$ \\
\hline 4 & 1.25 & $22.0 \pm 0.25$ & $1.7 \pm 0.12$ \\
\hline 5 & 1.50 & $11.0 \pm 0.30$ & $1.0 \pm 0.10$ \\
\hline 6 & 1.75 & $07.5 \pm 0.16$ & $0.9 \pm 0.06$ \\
\hline 7 & 2.00 & $04.5 \pm 0.10$ & $0.7 \pm 0.06$ \\
\hline
\end{tabular}

*All abbreviations are as mentioned in the text. 
Table 3 Effect of Using a Combination of Acid Activated Clay and Activated Carbon.

\begin{tabular}{c|c|c|c|c}
\hline \multirow{2}{*}{$\begin{array}{c}\text { Sr. } \\
\text { No. }\end{array}$} & \multicolumn{2}{|c|}{$\begin{array}{c}\text { Concentration of adsorbents } \\
(\%, \mathrm{w} / \mathrm{w})\end{array}$} & $\begin{array}{c}\text { Color of bleached oil } \\
\text { sample }(\mathrm{Y}+5 \mathrm{R})\end{array}$ & $\begin{array}{c}\text { Peroxide } \\
\text { Value } \\
(\mathrm{Meq} / \mathrm{kg})\end{array}$ \\
\cline { 2 - 3 } & $\mathrm{AAC}$ & $\mathrm{C}$ & $11.0 \pm 0.20$ & $1.0 \pm 0.10$ \\
\hline 1 & 1.50 & - & $16.0 \pm 0.30$ & $1.0 \pm 0.12$ \\
\hline 2 & 1.25 & 0.25 & $19.5 \pm 0.30$ & $1.8 \pm 0.12$ \\
\hline 3 & 1.00 & 0.50 & $25.0 \pm 0.20$ & $2.4 \pm 0.17$ \\
\hline 4 & 0.75 & 0.75 & & \\
\hline
\end{tabular}

*All abbreviations are as mentioned in the text.

Table 4 Wet Bleaching of Mustard Oil with Different Adsorbents.

\begin{tabular}{c|c|c|c|c|c}
\hline \multirow{2}{*}{$\begin{array}{c}\text { Sr. } \\
\text { No. }\end{array}$} & \multicolumn{2}{|c|}{$\begin{array}{c}\text { Concentration of } \\
\text { adsorbents }(\%, \mathrm{w} / \mathrm{w})\end{array}$} & $\begin{array}{c}\text { Color of bleached oil } \\
\text { sample } \\
(\mathrm{Y}+5 \mathrm{R})\end{array}$ & $\begin{array}{c}\text { Peroxide } \\
\text { Value } \\
(\mathrm{Meq} / \mathrm{kg})\end{array}$ \\
\cline { 2 - 6 } & $\mathrm{AAC}$ & $\mathrm{H}_{2} \mathrm{O}$ & $\mathrm{HC}$ & $09.0 \pm 0.30$ & $2.3 \pm 0.10$ \\
\hline 1 & 1.50 & 1.50 & - & $17.5 \pm 0.07$ & $2.7 \pm 0.16$ \\
\hline 2 & 1.25 & 1.25 & - & $22.5 \pm 0.10$ & $2.3 \pm 0.17$ \\
\hline 3 & 1.00 & 1.00 & - & $20.0 \pm 0.07$ & $2.8 \pm 0.16$ \\
\hline 4 & 1.00 & 2.00 & 1.00 & $20.0 \pm 0.20$ & $2.9 \pm 0.12$ \\
\hline 5 & 1.00 & 3.00 & 2.00 & $17.5 \pm 0.20$ & $2.8 \pm 0.17$ \\
\hline 6 & 1.25 & 1.00 & - & $22.0 \pm 0.20$ & $3.2 \pm 0.16$ \\
\hline 7 & 1.00 & 2.00 & 0.50 & $26.0 \pm 0.40$ & $3.7 \pm 0.16$ \\
\hline 9 & - & 2.00 & 2.00 & $27.0 \pm 0.07$ & $3.9 \pm 0.20$ \\
\hline
\end{tabular}

*Amount of $\mathrm{Al}(\mathrm{OH})_{3}$ Gel used

*All abbreviations are as mentioned in the text.

closer view of the results also show, that wet bleaching with AAC only is effective in reducing the color to acceptable level $(09.0 \pm 0.30$ to $17.5 \pm 0.07)$. Although wet bleaching with $\mathrm{HC}$ and $\mathrm{Al}(\mathrm{OH})_{3}$ gel reduce the color $(26.0 \pm 0.40$ and $27.0 \pm 0.07$ respectively) of oil but not to acceptable level. Maximum color reduction took place when wet bleaching was carried out with AAC $(1.5 \%, \mathrm{w} / \mathrm{w})$ and water was used at 1:1 (wt/wt) level with the adsorbent.

Use of $\mathrm{Al}(\mathrm{OH})_{3}$ gel is not reported earlier as adsorbent for color bodies from oils. Due to gel type structure of $\mathrm{Al}(\mathrm{OH})_{3}$ it was thought that it may appear as good adsorbent for oil pigments. Few batches of bleaching were therefore kept using different quantity of gel (1.0 to $6.0 \%, \mathrm{w} / \mathrm{w})$ only or along with AAC (0.5 to $1.5 \%, \mathrm{w} / \mathrm{w}), \mathrm{C}(0.5 \%, \mathrm{w} / \mathrm{w})$ and $\mathrm{S}$ $(1.7 \%, \mathrm{w} / \mathrm{w})$. Table 5 shows the bleaching ability of $\mathrm{Al}(\mathrm{OH})_{3}$ gel as such or in combination. These were used at different percentage level but the results show that the color improvement is not attractive. The results also show that none of these are good replacement for AAC. Use of $1.0 \%$, $\mathrm{w} / \mathrm{w}$ AAC reduces the color to $28.5 \pm 0.45$, whereas addition of $1.0 \%, \mathrm{w} / \mathrm{w}, \mathrm{Al}(\mathrm{OH})_{3}$ gel reduces the color to $27.0 \pm$ 0.20. Similarly, use of as high as $6.0 \%$, w/w, gel and 0.5 wt-percent AAC could reduce the color to only $26.0 \pm$ 0.35 .

To reduce the use of $\mathrm{AAC}$, different combinations of $\mathrm{HC}$ ( 0.5 to $6.0 \%$, w/w) containing $55.9 \%$, w/w, C) and AAC (e.g. 0.75 to $1.50 \%, \mathrm{w} / \mathrm{w})$ was used for bleaching. The results (Table 6) are found not to be satisfactory in respect of reduction in color. It was found that use of rice husk ash even at higher level (2.0 to $6.0 \%, \mathrm{w} / \mathrm{w})$ did not affect too much the color reduction. Use of even $6.0 \%, \mathrm{w} / \mathrm{w}$, rice husk ash along with $1.0 \%$, w/w, AAC resulted in color 
Table 5 Effect of Using $\mathrm{Al}(\mathrm{OH})_{3}$ Gel on Bleaching.

\begin{tabular}{|c|c|c|c|c|c|c|}
\hline \multirow{2}{*}{$\begin{array}{l}\text { Sr. } \\
\text { No. }\end{array}$} & \multicolumn{4}{|c|}{ Concentration of adsorbents $(\%, w / w)$} & \multirow{2}{*}{$\begin{array}{c}\text { Color of } \\
\text { bleached oil } \\
\text { sample }(Y+5 R)\end{array}$} & \multirow{2}{*}{$\begin{array}{l}\text { Peroxide } \\
\text { Value } \\
\text { (Meq/kg) }\end{array}$} \\
\hline & Ge1 & $\mathrm{AAC}$ & $\mathrm{C}$ & $\mathrm{S}$ & & \\
\hline 1 & 2.0 & - & - & - & $31.5 \pm 0.25$ & $4.3 \pm 0.17$ \\
\hline 2 & 4.0 & - & - & - & $29.5 \pm 0.25$ & $4.8 \pm 0.16$ \\
\hline 3 & 6.0 & - & - & - & $28.0 \pm 0.30$ & $4.8 \pm 0.12$ \\
\hline 4 & 1.5 & 0.5 & - & - & $31.0 \pm 0.35$ & $4.0 \pm 0.16$ \\
\hline 5 & 1.0 & 1.0 & - & - & $27.0 \pm 0.20$ & $2.2 \pm 0.06$ \\
\hline 6 & 4.0 & 0.5 & - & - & $27.0 \pm 0.07$ & $4.5 \pm 0.12$ \\
\hline 7 & 5.0 & 0.5 & - & - & $27.0 \pm 0.07$ & $4.4 \pm 0.16$ \\
\hline 8 & 6.0 & 0.5 & - & - & $26.0 \pm 0.35$ & $4.5 \pm 0.12$ \\
\hline 9 & 0.5 & 1.5 & - & - & $10.5 \pm 0.30$ & $1.0 \pm 0.06$ \\
\hline 10 & 2.5 & - & 0.5 & - & $32.5 \pm 0.30$ & $3.8 \pm 0.20$ \\
\hline 11 & 2.5 & - & - & 1.7 & $35.0 \pm 0.25$ & $3.6 \pm 0.17$ \\
\hline 12 & 4.0 & - & - & 1.7 & $27.5 \pm 0.35$ & $3.5 \pm 0.16$ \\
\hline
\end{tabular}

All abbreviations are as mentioned in the text.

Table 6 Effect of Using Rice Husk on Bleaching.

\begin{tabular}{c|c|c|c|c}
\hline \multirow{2}{*}{$\begin{array}{c}\text { Sr. } \\
\text { No. }\end{array}$} & \multicolumn{2}{|c|}{$\begin{array}{c}\text { Concentration of } \\
\text { adsorbents }(\%, \mathrm{w} / \mathrm{w})\end{array}$} & $\begin{array}{c}\text { Color of bleached oil } \\
\text { sample }(\mathrm{Y}+5 \mathrm{R})\end{array}$ & $\begin{array}{c}\text { Peroxide } \\
\text { Value } \\
(\mathrm{Meq} / \mathrm{kg})\end{array}$ \\
\cline { 2 - 3 } 1 & AAC & HG & & $2.6 \pm 0.16$ \\
\hline 2 & 0.75 & 0.5 & $27.0 \pm 0.35$ & $2.3 \pm 0.10$ \\
\hline 3 & 1.00 & 0.5 & $24.5 \pm 0.07$ & $0.9 \pm 0.06$ \\
\hline 4 & 1.50 & 0.5 & $10.5 \pm 0.35$ & $5.3 \pm 0.16$ \\
\hline 5 & 1.00 & 2.0 & $27.5 \pm 0.20$ & $1.9 \pm 0.10$ \\
\hline 6 & 1.00 & 3.0 & $25.5 \pm 0.25$ & $2.0 \pm 0.10$ \\
\hline 7 & 1.00 & 4.0 & $23.0 \pm 0.07$ & $1.6 \pm 0.12$ \\
\hline 8 & 1.00 & 5.0 & $21.0 \pm 0.20$ & $1.5 \pm 0.06$ \\
\hline 9 & 1.00 & 6.0 & $19.5 \pm 0.35$ & $1.6 \pm 0.10$ \\
\hline
\end{tabular}

All abbreviations are as mentioned in the text.

value of $18.0 \pm 0.07 \%$. When bleaching was carried out using only AAC at 1.0 and $1.5 \%, \mathrm{w} / \mathrm{w}$, level the color values observed for the resultant oil was $28.5 \pm 0.45$ and $11.0 \pm$ 0.30 respectively. Whereas, when $\mathrm{HC}$ was used at $0.5 \%$, $\mathrm{w} / \mathrm{w}$, level with the above mentioned percentages of AAC the observed color values was $24.5 \pm 0.07$ and $10.5 \pm 0.35$. Peroxide value is also found to be reduced to acceptable range except in one sample $(5.3 \pm 0.16 \mathrm{meq} / \mathrm{kg})$ where only $2.0 \% \mathrm{HC}$ was used for bleaching.

Along with AAC, AC (acid activated rice husk ash containing carbon) and S (rice husk silica) were also used for the bleaching of mustard oil. The volumetric mean diameter (VMD) of the particles is $86.8 \mu \mathrm{m} ; 10,16,50,84,90$ and $99 \%$ (by-vol) of the particles passes through mesh sizes of 
Table 7 Effect of Acid Activation of Rice Husk Silica on Bleaching.

\begin{tabular}{c|c|c|c|c|c}
\hline \multirow{2}{*}{$\begin{array}{c}\text { Sr. } \\
\text { No. }\end{array}$} & \multicolumn{2}{|c|}{$\begin{array}{c}\text { Concentration of } \\
\text { adsorbents }(\%, \mathrm{w} / \mathrm{w})\end{array}$} & $\begin{array}{c}\text { Color of bleached oil } \\
\text { sample }(\mathrm{Y}+5 \mathrm{R})\end{array}$ & $\begin{array}{c}\text { Peroxide } \\
\text { Value } \\
\text { (Meq/kg) }\end{array}$ \\
\cline { 2 - 5 } & AAC & AC & $\mathrm{S}$ & $10.0 \pm 0.25$ & $1.6 \pm 0.06$ \\
\hline 1 & 1.5 & 0.5 & - & $25.0 \pm 0.20$ & $1.9 \pm 0.12$ \\
\hline 2 & 1.0 & 1.0 & - & $19.5 \pm 0.25$ & $2.0 \pm 0.10$ \\
\hline 3 & 1.0 & 2.0 & - & $19.0 \pm 0.7$ & $1.9 \pm 0.12$ \\
\hline 4 & 1.0 & 3.0 & - & $26.5 \pm 0.25$ & $2.6 \pm 0.16$ \\
\hline 5 & 0.5 & 3.0 & - & $32.5 \pm 0.30$ & $4.0 \pm 0.17$ \\
\hline 6 & - & 2.0 & - & $29.0 \pm 0.07$ & $3.9 \pm 0.17$ \\
\hline 7 & - & 4.0 & - & $32.5 \pm 0.10$ & $4.8 \pm 0.20$ \\
\hline 8 & - & - & 2.0 & $27.0 \pm 0.07$ & $4.2 \pm 0.20$ \\
\hline 9 & - & - & 4.0 & $24.5 \pm 0.07$ & $1.9 \pm 0.12$ \\
\hline 10 & 1.0 & - & 1.0 & $20.0 \pm 0.20$ & $1.8 \pm 0.06$ \\
\hline 11 & 1.0 & 0.5 & 0.5 & $22.5 \pm 0.30$ & $2.5 \pm 0.12$ \\
\hline 12 & 0.5 & 0.5 & 1.0 & $20.0 \pm 0.35$ & $1.4 \pm 0.10$ \\
\hline 13 & 1.0 & 1.0 & 0.5 & & \\
\hline
\end{tabular}

All abbreviations are as mentioned in the text.

17.32, 25.72, 62.81, 147.19, 189.56 and $365.09 \mu \mathrm{m}$, respectively. During this study the quantity of AAC used was restricted to 0.5 to $1.5 \%, \mathrm{w} / \mathrm{w}$ (Table 7 ). When only $\mathrm{AC}$ or $\mathrm{S}$ was used for bleaching it was used as high as $4.0 \%, \mathrm{w} / \mathrm{w}$ level. The results show that a minimum quantity of $1.0 \%$, $\mathrm{w} / \mathrm{w} \mathrm{AAC}$ is required to have a color of acceptable level (i.e. less than 20) when either AC or S is used along with it. Peroxide value although drastically reduced in all the bleached oil samples but has a bit of higher values where AAC was not used or used at lower level. Finally it is worthy to mention that all the results shown in Table 1-7 are the arithmetic mean with their standard deviations of 3 sets of results.

\section{CONCLUSION}

The entire study shows that rice husk ash (containing carbon) and rice hush silica (acid treated) can be used for partial replacement of commercial AAC, although the quantity of these materials to be used is few times more than the AAC used. Aluminium hydroxide gel appeared to be ineffective adsorbent for pigments of oil.

\section{ACKNOWLEDGEMENTS}

The authors are indebted to The Director, Institute of Science \& Technology for Advanced Studies \& Research (ISTAR), Vallabh Vidyanagar, Anand, India, for providing the infrastructural facility for smooth conduction of this study.

\section{References}

1. Andersen, A.J.C. Refining of Oils and Fats for Edible Purposes (Williams, P.N. ed.). Pergamon Press. OxfordLondon (1962).

2. Pryor, J.N.; Bogdanor, J.M.; Welsh, W.A. US pat. 4781864 (1988).

3. Thomopoulos, C.D.; Tzia, C.E.; Papathanasiou, K.G.; Anghelopoulou, I.E. Chem. Abstr. 112, p.196832w (1990).

4. Pryor, J.N.; Bogdanor, J.M.; Welsh, W.A. US pat. 4877765 (1989).

5. Proctor, A.; Palaniappan S. Soy oil lutein adsorption by rice hull ash. J. Am. Oil Chem. Soc. 66, 1618-1621 (1989).

6. Liew, K.Y.; Yee, A.H.; Nordin, M.R. Adsorption of carotene from palm oil by acid treated rice hull ash. $J$. Am. Oil Chem. Soc. 70, 539-541 (1993).

7. Gopala Krishna, A.G. A method for bleaching rice bran 
oil with silica gel, J. Am. Oil Chem. Soc. 69, 12571259 (1992).

8. Katzer, A.; Wegrowski, J.; Platek, T.; Jerzewska, M.; Rajeh, B. Chem. Abstr. 125, p.171492r (1996).

9. IUPAC Standard Methods for the Analysis of Oils, Fats and Derivatives, Methods 2.103; 2.201; 2.202;
2.205; $2.501\left(7^{\text {th }}\right.$ edn.). Blackwell Scientific Publications, Oxford (UK) (1987).

10. Chen, P.S. Jr.; Toribara, T.Y.; Warner, H. Micro determination of Phosphorus. Anal. Chem. 28, 1756-1758 (1956). 